\title{
Influence of Dietary Zinc Methionine Supplementation on Eggshell Quality in Laying Hens under Hot Climate Environment
}

\author{
Kazumi Kita, Isao Hohmura* and Jun-ichi Okumura \\ School of Agriculture Sciences, Nagoya University, Nagoya \\ 464-01, *Aichi-ken Agricultural Research Center, 1-1 \\ Sagamine, Yazako, Nagakute, Aichi 480-11
}

\begin{abstract}
We have examined the influence of dietary zinc-methionine ( $\mathrm{Zn}-\mathrm{Met} ; \mathrm{Zn} 80 \mathrm{~g} / \mathrm{kg}$,

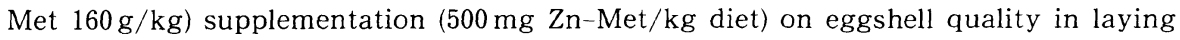
hens under hot climate environment. The experiment was started from June 15, 1995 and continued for 12 weeks. The egg production and the quality of eggshell were measured at $0,4,8$ and 12 weeks of experiment.

The average of daily maximum temperatures in the first week was $25.5^{\circ} \mathrm{C}$ and then increased gradually until 8 weeks of experiment $\left(37.5^{\circ} \mathrm{C}\right)$. Thereafter it was kept for 3 weeks and then decreased toward the end of the experiment. The rate of egg production at 4 weeks of experiment was significantly lower than that at the beginning of experiment. The number of abnormal eggs changed similarly to the variation of ambient temperatures. Eggshell weight decreased significantly from 0 to 8 weeks of experiment and thereafter increased significantly. Eggshell thickness at 8 weeks of experiment was the thinnest through the experimental period. Eggshell strength decreased gradually from 4 to 8 weeks of experiment and then increased significantly. Dietary Zn-Met supplementation did not affect eggshell quality. These results suggest that poor eggshell quality under hot climate environment was not improved by dietary Zn-Met supplementation at the level tested.
\end{abstract}

(Jpn. Poult. Sci., 34:21-26, 1997)

Key words : Laying hens, high temperature, zinc methionine, egg production, eggshell quality

\section{Introduction}

It has been well recognized that high ambient temperature has negative influence on egg quality. The increase in environmental temperature reduced egg weight (Stockland and Blaylock, 1974 ; DeAndrade et al., 1977 ; Vohra et al., 1979) and eggshell weight (HARrison and Biellier, 1969). Mongin (1968) reported that the negative influence of high ambient temperature on egg shell formation is, in part, due to the decrease in plasma concentration of bicarbonate in laying hens exposed under high ambient temperature.

Zinc-methionine (Zn-Met), which is one of metal-amino acid complexes, has been used for improving the performance of laying hens. Harbaugh and SANFord (1970) found that dietary $\mathrm{Zn}$-Met supplementation increased egg production and body weight. The positive effect of additive $\mathrm{Zn}$-Met on the performance of laying hens is resulted from the higher bioavailability of zinc compared to inorganic zinc sources 
(WEDEKIND et al., 1992).

Yoselewitz and BaLnave (1989) found that eggshell quality was reduced in laying hens receiving saline drinking water. Recently MoRENG et al. (1992) have reported that dietary $\mathrm{Zn}$-Met overcame the negative influence of the saline drinking water on eggshell quality. These findings propose the potency of dietary Zn-Met supplementation to overcome the negative influence of high ambient temperature on eggshell quality. In the present study, therefore, the effect of dietary Zn-Met supplementation on eggshell quality under hot climate environment was examined.

\section{Materials and Methods}

To examine the effect of dietary $\mathrm{Zn}$-Met supplementation on eggshell quality under hot climate environment, the experiment was started from June 15, 1995 and continued for 12 weeks. In this experiment, 100 single-comb White Leghorn laying hens $(60$-week-old $(n=50), 82$-week-old $(n=50))$ were used. At the beginning of experiment, laying hens at the same age were divided evenly into 2 experimental groups (control vs. Zn-Met supplementation) of 25 birds each. In the control group, laying hens were allowed free access to a practical diet based on yellow-corn, soybean meal and fish meal (CP 18.1\%; ME 2,890 kcal $/ \mathrm{kg}$ ). Laying hens in the $\mathrm{Zn}$-Met supplementation group were given $\mathrm{Zn}$-Met supplemented diet prepared by adding 500 $\mathrm{mg} / \mathrm{kg}$ diet of Zn-Met (Master Mix ZM-80 ${ }^{\mathrm{TM}} ; \mathrm{Zn} 80 \mathrm{~g} / \mathrm{kg}$; Met $160 \mathrm{~g} / \mathrm{Kg}$; Nihon-Soda Co. Ltd., Tokyo) to the practical diet. All birds were kept at Aichi-ken Agricultural Research Center, Nagakute, Aichi. The daily maximum and minimum ambient temperatures were measured. Body weights were measured every 4 weeks. Food intakes for 4 weeks were measured at 4, 8 and 12 weeks of experiment. All eggs were collected for 4 days before 4, 8 and 12 weeks of experiment, and egg production, egg weight, eggshell weight, eggshell strength and eggshell thickness were measured. The number of abnormal eggs (i.e. shell-less eggs, soft-shell eggs and cracked eggs) was also counted. Statistical analysis of data was performed by three-way split-plot analysis (CoCHRAN and Cox, 1992) using the General Linear Model Procedures (SAS/ STAT Version 6, SAS Institute, Cary NC), in which dietary treatment and age were main-effects and experimental period was sub-effect.

\section{Results}

The weekly averages of daily maximum and minimum ambient temperatures in a poultry house are shown in Fig. 1. The average of daily maximum and minimum temperatures at the first week of experiment were 25.5 and $16.8^{\circ} \mathrm{C}$, respectively. The maximum temperature increased from 0 to 8 weeks of experiment and the highest temperature was $37.5^{\circ} \mathrm{C}$ at 8 weeks of experiment. There after it was kept for 3 weeks and then decreased toward the end of experiment. The change in weekly average of daily minimum temperatures showed similar tendency to that in maximum temperatures.

Body weight increased slightly but significantly $(\mathrm{P}<0.05)$ from 0 to 4 weeks of age and from 8 to 12 weeks of age. Food intakes decreased significantly $(\mathrm{P}<0.05)$ through 
the experimental period. No significant influence of $\mathrm{Zn}$-Met supplementation on both body weights and food intakes was observed.

The rate of egg production, eggshell quality and the change in egg weight over 12 weeks of the experimental period are shown in Table 1. No influence of age and dietary $\mathrm{Zn}$-Met supplementation was observed in all variables. The rate of egg production decreased significantly from 0 to 4 weeks of experiment and thereafter no change was observed until the end of experiment. The number of abnormal eggs varied similarly to the change in ambient temperature. Egg weights decreased from 4 to 8 weeks of experiment and then increased from 8 to 12 weeks of experiment.

The change in eggshell weight, eggshell thickness and eggshell strength over experimental periods are shown in Table 2. There was no influence of age and $\mathrm{Zn}-$ Met supplementation on all determinants of eggshell. Eggshell weight decreased significantly from 0 to 8 weeks of experiment and then increased from 8 to 12 weeks of experiment. Eggshell thickness at 8 weeks of experiment was the thinnest of all. Eggshell strength tended to decrease from 4 to 8 weeks of experiment and then increased significantly toward 12 weeks of experiment.

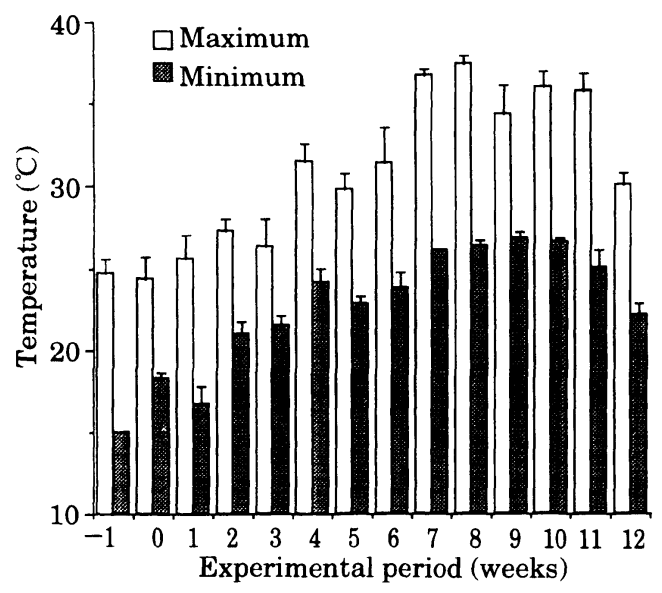

Fig. 1. Changes in the average of daily maximum and minimum temperatures during experimental periods.

Table 1. Influence of dietary zinc methionine (Zn-Met) supplementation on egg production, egg weight, eggshell weight, eggshell thickness and eggshell strength

\begin{tabular}{lccc}
\hline & Control & Zn-Met & P value \\
\hline Egg production $\left(\right.$ hen $^{-1} .4$ days $\left.^{-1}\right)$ & $2.88 \pm 0.081$ & $2.91 \pm 0.089$ & 0.90 \\
Egg weight $(g)$ & $68.4 \pm 0.29$ & $67.8 \pm 0.26$ & 0.62 \\
Eggshell weight $(\mathrm{g})$ & $6.10 \pm 0.032$ & $5.92 \pm 0.033$ & 0.09 \\
Eggshell thickness $(\mu \mathrm{m})$ & $33.9 \pm 0.14$ & $33.3 \pm 0.16$ & 0.19 \\
Eggshell strength (arbitrary unit) & $3.21 \pm 0.038$ & $3.25 \pm 0.038$ & 0.98 \\
\hline
\end{tabular}

Means were not significantly different between control and $\mathrm{Zn}-\mathrm{Met}$ at $\mathrm{P}<0.05$. 
Table 2. Changes in eggshell weight, eggshell thickness and eggshell strength during the experimental period

\begin{tabular}{lccccc}
\hline \multicolumn{1}{c}{ Weeks } & 0 & 4 & 8 & 12 & Pooled SEM \\
\hline Eggshell weight $(\mathrm{g})$ & $6.19^{\mathrm{a}}$ & $5.98^{\mathrm{c}}$ & $5.73^{\mathrm{d}}$ & $6.08^{\mathrm{b}}$ & 0.024 \\
Eggshell thickness $(\mu \mathrm{m})$ & $34.0^{\mathrm{a}}$ & $33.6^{\mathrm{a}}$ & $32.6^{\mathrm{b}}$ & $34.0^{\mathrm{a}}$ & 0.14 \\
Eggshell strength (arbitrary unit) & $3.27^{\mathrm{ab}}$ & $3.20^{\mathrm{ab}}$ & $3.16^{\mathrm{b}}$ & $3.29^{\mathrm{a}}$ & 0.042 \\
\hline
\end{tabular}

Means sharing a different superscript are significantly different at $\mathrm{P}<0.05$.

\section{Discussion}

It has been well-known that high environmental temperatures bring about marked reduction in egg production and eggshell quality. The present study was conducted to examine whether dietary $\mathrm{Zn}$-Met supplementation improved egg production and eggshell quality under hot climate environment. As shown in Fig. 1, during first 8 weeks of experiment, the weekly average of daily maximum temperatures increased from $25.5^{\circ} \mathrm{C}$ to $37.5^{\circ} \mathrm{C}$. The large variation in ambient temperatures confirmed that the influence of high environmental temperature on egg production and eggshell quality could be successfully examined in the present study.

The decrease in egg production and the increase in the number of abnormal eggs along with increased ambient temperatures are supported by the previous findings reported by many researchers (STOCKLAND and BLAYLOCK, 1974 ; DEANDRADE et al., 1977 ; VoHra et al., 1979). The increase in egg production by the supplementation of $\mathrm{Zn}-\mathrm{Met}$ reported by HARBAUGH and SANFORD (1970) led to expectation to prevent egg production from decreasing under hot climate environment. In the present study, however, no positive effect of dietary $\mathrm{Zn}$-Met supplementation on egg production was observed, even though the higher bioavailability of $\mathrm{Zn}$-Met compared to inorganic $\mathrm{Zn}$ sources was reported (WEDEKIND et al., 1992). The positive effect of $\mathrm{Zn}$-Met on egg production was reported when laying hens were given diets with $1,800 \mathrm{mg} \mathrm{Zn-Met/kg} \mathrm{(HARBAUGH}$ and SANFORD, 1970). The $500 \mathrm{mg} \mathrm{Zn}-\mathrm{Met} / \mathrm{kg}$ examined in the present study might be insufficient for preventing egg production from decreasing in hot environment temperatures.

Yoselewitz and Balnave (1989) suggested that reduced activity of carbonic anhydrase in the shell gland mucosa of laying hens receiving drinking saline water might be a major factor limiting eggshell quality. Moneng et al. (1992), thereafter, demonstrated that dietary $\mathrm{Zn}-\mathrm{Met}$ is effective in overcoming the negative influence of the saline drinking water on eggshell quality resulting in the improvement of shell breaking strength and shell defects. Therefore the potency of $\mathrm{Zn}$-Met to improve the reduced egg production and eggshell quality under hot climate environment was expected because zinc is an integral component of carbonic anhydrase. In the present study, however, no improvement of eggshell quality by dietary Zn-Met supplementation was observed. This may result that $\mathrm{Zn}$-Met supplementation at the level tested failed to improve the reduced activity of carbonic anhydrase under hot climate environment, and the influence of higher levels of $\mathrm{Zn}$-Met supplementation on egg 
production and eggshell quality of laying hens exposed high environmental temperatures should be examined in the future.

\section{References}

Cochran, W.G. and G.M. Cox (1992) Factorial experiments with main effects confounded: Splitplot designs. In 'Experimental Designs. 2nd edition'. pp 293-316. John Wiley \& Sons, Inc. New York.

DeAndrade, A.N., J.C. Rogler, V.R. Featherston and C.W. Alliston (1977) Interrelationships between diet and elevated temperature on egg production and shell quality. Poultry Science $56: 1178-1183$.

HaRbaugh, D.D. and P.E. SANFord (1970) The effect of various levels of zinc-methionine supplement on flock performance, egg size and shell quality. Poultry Science 49: 1393.

HARRISON, P.C. and H.V. Biellier (1969) Physiological response of domestic fowl to abrupt change of ambient air temperature. Poultry Science 48 : 1034-1045.

Mongin, P.E. (1968) Role of acid-base balance in the physiology of egg-shell formation. World's Poultry Science Journal $24: 200-230$.

Moreng, R.E., D. BALnAve and D. Zhang (1992) Dietary zinc methionine effect on eggshell quality of hens drinking saline water. Poultry Science $71: 1163-1167$.

STOCKLAND, W.L. and L.G. BLAYLOCK (1974) The influence of temperature on the protein requirement of cage-reared replacement pullets. Poultry Science $53: 1174-1187$.

VoHRA, P., W.O. WILSON and T.D. Siopes (1979) Egg production, feed consumption, and maintenance energy requirement of Leghorn hens at temperatures of 15.6 and $26.7^{\circ} \mathrm{C}$. Poultry Science 58 : 674-680.

WeDEKIND, K.J., A.E. HoRTIN and D.H. BAKER (1992) Methodology for assessing zinc bioavailability : efficiency estimates for zinc-methionine, zinc sulfate, and zinc oxide. Journal of Animal Sciences $70: 178-187$.

Yoselewitz, I. and D. Balnave (1989) The influence of saline drinking water on the activity of carbonic anhydrase in the shell gland of laying hens. Australian Journal of Agricultural Research 40 : 1111-1115. 


\section{高温環境下における卵款の品質におよぼす飼料への \\ 亜鉛メチオニン添加の影響 \\ 喜多一美1) 法邑 勲 ${ }^{2)} \cdot$ 奥村純市 $^{1)}$ \\ 1) 名古屋大学農学部, 名古屋市 464-01 \\ 2) 愛知県農業総合試験場養鷄研究所, 愛知郡長久手町 480-11}

高温環境下における産卵鶏の卵款品質におよぼす飼料 への亜鉛メチオニン $(\mathrm{Zn}-\mathrm{Met}$; 亜鉛含量 $80 \mathrm{~g} / \mathrm{kg}$, メチ オニン含量 $160 \mathrm{~g} / \mathrm{kg}$ ) 添加 (500 mg Zn-Met/kg diet) の影響について調査した。実験は，1995年 6 月 15 日か ら 12 週間にわたって行った。

実験開始 1 週間における日中最高気温の平均值は $25.5^{\circ} \mathrm{C}$ であり, 実験開始後第 8 週まで上昇した $\left(37.5^{\circ} \mathrm{C}\right)$ 。最高気温は, その後 3 週間有意差はなく, それ 以後, 実験終了時まで低下していった。実験開始後第 4 週における産卵率は, 実験開始時より有意に低かった。 異常卵の数は, 気温の変動と同様に変動した。卵款重量
は, 0 から 8 週にかけて減少し，その後有意に増加した。 第 8 週における卵殻厚が、実験期間中最も薄かった。卵 款強度は, 第 4 週から第 8 週にかけて低下し, その後有 意に上昇していった。飼料への亜鉛メチオニン添加は, 卵殻の品質に影響をおよぼさなかった。以上の結果か ら，本研究で用いたレベルの飼料への亜鉛メチオニン添 加では, 高温環境下における卵殼の品質の低下を改善で きないことが示された。

（家禽会誌，34:21-26, 1997） キーワード : 産卵䊿, 高温, 亜鉛メチオニン, 産卵, 卵款 品質 